\title{
Ausencia
}

Tengo sequía en el cuerpo y para remediar este vacío trago náufragos, barcos, e islas completas.

Camino al ritmo de las olas, añorando sentir las grietas de las ostras celestes contra mi piel.

Me sumerjo en este océano de efigies desastradas, atravieso el sargazo que cubre la delicada tez del agua.

Palpo tu ausencia en los huesos del cardumen, a la distancia resuena tu nombre azotado contra las piedras de la ribera.

Observo tu reflejo en la marea, me hundo, me ahogo, me desmorono en este fuego mudo que no arde por sí mismo pero quema adentro.

El aire se enrama con tu voz, la neblina forma palabras que nunca podré llegar a entender. 
Se prohíbe su reproducción total o parcial por cualquier medio, incluido electrónico, sin permiso previo y por escrito de los editores.

DIÁLOGO DE POETAS

\section{Las persigo,} las persigo, las persigo, abro los ojos y la linfa atesta mis pulmones deshabitados.

La brisa que exhala

el carmín de mis mejillas me dice que lo que fue

ya no será nunca más. 
Se prohíbe su reproducción total o parcial por cualquier medio, incluido electrónico, sin permiso previo y por escrito de los editores. 